\title{
PRODUCTION CAPACITY OF BULGARIAN ORGANIC ANIMAL HUSBANDRY
}

\author{
G. Aleksiev*, D. Doncheva \\ Faculty of Economics, Trakia University, Stara Zagora, Bulagria
}

\begin{abstract}
The actuality of organic farming is revealed as an important policy priority for Bulgarian agriculture and one of the highlights of the Common Agricultural Policy (2014-2020) encouraging farmers to switch to organic farming which should contribute to both: protection of the environment and production of healthy food.

The purpose of the study is to assess the production capacity of Bulgarian organic animal husbandry, as a base for its further development and as a result of the social support towards it.

To reach this goal the study should accomplish three tasks:

- $\quad$ Assessing the level of production of Bulgarian organic animal husbandry

- Presenting and analyzing the social support framework for the sector

- Offer a conclusion and recommendations for the implementation of the Common agricultural policies of the EU and improvements of the production capacity of the sector.

The production capacity of bio-farms is linked to their economic performance and ability to provide the necessary income for the owner and employees. Public support for this type of production has a favorable effect on the economic situation of the sector, but access to the resources provided by the CAP is linked to the still significant administrative difficulties and a high level of transaction costs.
\end{abstract}

Key words: agriculture, organic products, social support

\section{INTRODUCTION}

Organic farming guarantees sustainability, fairness, food and climate security. It can restore the fertility of the soil, end the desertification, extract the accumulated carbon in the atmosphere and improve the soil composition.

In recent years, organic farming in Bulgaria is one of the sectors that is developing at a rapid pace in times of sector wide degradation, with constantly increasing areas and the number of producers included in the control system. The reasons behind this development are related to the very good conditions in our country for its progress - ecologically preserved regions; awareness and willingness of consumers to eat healthily; realized environmental and rural benefits; support for organic producers combined with positive reception of Bulgarian organic products on foreign markets. The aim of the present study is to analyze the production potential and trends in the

*Correspondence to: Georgi Aleksiev Faculty of Economics, Trakia University - Stara Zagora, Studentski grad, 6000 Stara Zagora, Bulagria, 042/699428,E-mail: georgi.alexiev@gmail.com development of organic animal farming in Bulgaria.

In order to achieve the goal, the following tasks are solved:

- To analyze the state of organic farming in Bulgaria;

- To reveal trends in the development of organic farming;

- To identify the problems and to summarize the recommendations for the development of the Bulgarian organic animal husbandry.

The methods used to solve tasks and achieve the goal are systematic and comparative analysis; conceptually constructive; method of statistical groupings, inductive and deductive methods for generalizing summaries.

The organic farming scheme was launched in the EU in 1987, with Denmark being a pioneer among European countries. The 1992 reform of the Common Agricultural Policy (CAP) presents the first ground for helping farmers to move to or maintain organic production with EU funding $(1,2)$.

Globally, the European Union is one of the main producers of organic food. In 2011, about 
37 million hectares are managed in a biological way worldwide. Most of the organic areas are located in Oceania (12.2 million hectares) and Europe (10.60 million hectares, of which more than 9.5 million hectares are in the EU within nearly 240,000 farms) (3).

According to the FAO and the WHO Codex Alimentarius (4, 5): Organic farming is "a comprehensive production management system that supports sustainability in agroecosystems, bio-diversity, biological cycles and biological activity in the soil". The emphasis is on mobilizing the farm's internal resources while minimizing externalities. The biological system takes into account the fact that regional (local) conditions require agrosystems adapted to the specific region. This is achieved through agronomic, biological and technical methods as opposed to synthetic inputs.

Organic farming and animal husbandry is a specific production method that maintains environmental balances and produces foodstuffs that cover the principles of the environmental cycles "plants - animals - soil" (6). Organic farming contributes to the sustainable development of rural areas, the protection of the environment and ensures good conditions for animal welfare.

The necessity of development of organic agriculture is relevant to the following problems in the contemporary Bulgarian agriculture:

- Concentration and specialization of production - disturbance of the biological equilibrium in nature;

- $\quad$ Reduced biodiversity and destruction of beneficial species;

\section{ALEKSIEV G., et al.}

- Pest resistance to chemicals and deepening of environmental problems;

- $\quad$ Fragmentation of land;

- $\quad$ Operating old equipment and buildings not complying with EU standards;

- Deficiency or excessive use of plant protection products without taking into account the soil and climatic features of the area;

- Inability to use EU funds to support farmers - lack of information and training.

The agglomeration of the Bulgarian agrarian sector and the specialization in the production of grain and technical crops determine the leading role of big farms. This contributes to the small share of bio-farms in the country's total agrarian production. Strict regulatory requirements do not allow the deployment of large-scale farms, and in some cases the legal framework makes this absolutely impossible. Due to this fact, there are a number of problems facing organic farming for small agrarian farms - the regulated possibilities for direct supply of small quantities of raw materials and food products cannot have a significant positive effect on small farms as the requirements imposed imply significant additional costs (Balieva, 2015) (7).

Despite all the problems noted here, organic production in Bulgaria marks a fast pace of development, which places Bulgaria at seventh place in the world in terms of the area grown according to the requirements for organic production, according to FiBL \& IFOAM (2015) (8).

In organic livestock, there is also a positive trend, according to the data presented in Table 1 (9).

Table 1. Organically grown live animals

\begin{tabular}{|l|l|l|l|l|l|l|l|l|l|l|}
\hline & $\mathbf{2 0 0 6}$ & $\mathbf{2 0 0 7}$ & $\mathbf{2 0 0 8}$ & $\mathbf{2 0 0 9}$ & $\mathbf{2 0 1 0}$ & $\mathbf{2 0 1 1}$ & $\mathbf{2 0 1 2}$ & $\mathbf{2 0 1 3}$ & $\mathbf{2 0 1 4}$ & $\mathbf{2 0 1 5}$ \\
\hline Cattle & 329 & 395 & 470 & 272 & 364 & 976 & 1173 & 1311 & 1622 & 4209 \\
\hline Sheep & 1054 & 1690 & 2471 & 5831 & 6698 & 6648 & 9175 & 7894 & 9029 & 18792 \\
\hline Goats & 131 & 1058 & 1624 & 2732 & 2773 & 3397 & 2831 & 3235 & 4142 & 5381 \\
\hline $\begin{array}{l}\text { Bee } \\
\text { colonies }\end{array}$ & 33981 & 35747 & 44861 & 41089 & 46429 & 58855 & 85346 & 117360 & 106676 & $\begin{array}{l}17833 \\
1\end{array}$ \\
\hline
\end{tabular}

Source: Author calculations based on data from Agrostatistics

The number of animals reared with the organic farming methods in Bulgaria is increasing. The largest increase was registered by goats - from 131 in 2006 to 5381 in 2015, or 41 times. The sheep also have a significant increase in their numbers - about 18 times compared to 2006. In 2015 alone the number of sheep, grown organically has doubled (10).
In the system of control in 2015 there are also 178331 bee colonies (for 2006 there were 33 981). A prerequisite for the increase in recent years is the good intake of organic honey on the European and world markets. Honey production increases from 1263 tons in 2011 to 1554 tons in 2015, most of which is exported to the world market. (11) 
The still underdeveloped internal market for bio-products and their shorter shelf-life make the construction of product marketing channels a major problem for the sector. For products that are not limited by their short shelf-life, there is a markedly faster growth rate of units. According to FiBL \& IFOAM (2015) (12), Bulgaria ranks third in the world by number of bee families included in control systems. The ability of bee products to retain their characteristics unchanged over a long period of time allows their trading on international markets without any restrictions. The growth rates of organic production in the country clearly show the comparative advantages Bulgaria has in the production of these specific products. For the further development of the sector, the increasing demands of consumers worldwide will play an increasingly important role as well as the institutional support for producers wishing to participate in the control system.

Pursuant to Regulation № 4 of 24.02.2015 (13) on the implementation of Measure 11 "Organic farming" of the RDP for the period 2014-2020 the financial support for carrying out biological activities is provided in the form of annual payments, with $75 \%$ of the funds being provided from the EU and $25 \%$ from the budget of the Republic of Bulgaria. The annual amount of payments is presented in Table 2.

Table 2. Annual payments for organic farming.

\begin{tabular}{|l|l|l|}
\hline Activities & In transition & Past transition \\
\hline 1.Main crops, including fodder & $284 \mathrm{euro} / \mathrm{ha}$ & $168 \mathrm{euro} / \mathrm{ha}$ \\
\hline 2. Permanent grassland & $128 \mathrm{euro} / \mathrm{ha}$ & $112 \mathrm{euro} / \mathrm{ha}$ \\
\hline 3. Perennials, vines, oil rose & $736 \mathrm{euro} / \mathrm{ha}$ & $557 \mathrm{eur} / \mathrm{ha}$ \\
\hline 4. Aromatic and medicinal plants & $515 \mathrm{euro} / \mathrm{ha}$ & $405 \mathrm{euro} / \mathrm{ha}$ \\
\hline 5. Vegetable crops & $575 \mathrm{euro} / \mathrm{ha}$ & $399 \mathrm{eur} / \mathrm{ha}$ \\
\hline 6. For the Bee Family & $35 \mathrm{euro} / \mathrm{ha}$ & $25 \mathrm{euro} / \mathrm{ha}$ \\
\hline 7. Large ruminants (cattle and buffalo) grown for milk & $230 \mathrm{euro} / \mathrm{ha}$ & $77 \mathrm{eur} / \mathrm{ha}$ \\
\hline 8. Large ruminants (cattle and buffalo) grown for meat & $160 \mathrm{euro} / \mathrm{ha}$ & $63 \mathrm{euro} / \mathrm{ha}$ \\
\hline 9. Small ruminants (sheep and goats) for milk and meat & $122 \mathrm{euro} / \mathrm{ha}$ & $90 \mathrm{eur} / \mathrm{ha}$ \\
\hline
\end{tabular}

Source: Regulation №4 from 24.02.2015. For the application of Measure 11 „Organic farming“ of PRD for the period 2014-2020

The organic market in Bulgaria outpaces production. The majority (over $80 \%$ ) of organic foods in Bulgaria are exported mainly on the European market - mostly in Germany, the Netherlands, France, and Italy. There are also exports to the USA, Japan, Korea and Canada. Bulgaria is one of the largest exporters of wild dried berries and herbs. Exotic fruits, strawberries, raspberries, organic honey, essential oils of rose, lavender, mint, cheese, and jams are exported and received very well on the international market. Bulgarian bio products are competitive on foreign markets because of their quality, lower production cost and are thus offered at lower prices, are in accordance with all regulations and standards and are unique in their characteristics.

Organic farming in Bulgaria is at an early stage of its development, but the trends are ascending and it is developing at a rapid pace. For the period 2006-2015, the number of organic operators and the areas in organic production has increased over 15 times, the number of cattle and bee families has increased respectively 12 and 5 times, the number of sheep - 18 times and the number of goats - 41 times.
With the launch of the new Rural Development Program (RDP) for the 2014-2020 (14, 15) period, the expectations for the development of organic farming are increasing as EU funding for organic farming is increased 5 times (33 million euros were planned in the previous RDP, and 152 million euros in the new one). For the first time, funding for organic livestock farming is also planned, and measures such as pastoralism (seasonal grazing), conservation of endangered local breeds and other activities are also planned.

\section{CONCLUSIONS AND RECOMMENDATIONS}

Bulgaria has favorable opportunities for the development of organic farming, the main ones being summarized as follows:

- Appropriate soil and climatic conditions;

- An existing set of knowledge and skills;

- Functioning system of scientific, training and consulting units;

- Positive image of Bulgarian agricultural products (foods) on the domestic and foreign markets;

- Availability of production capacity in the food industry;

- Rising demand for organic products. 
In order to realize these opportunities in a timely manner, it is necessary to apply appropriate measures, some of which may be: - Lowering the taxation level on organic products;

- Stricter controls and sanctions in unfair competition from products labeled "eco";

- Support of promotional activities and other marketing initiatives for the distribution of bio products;

- Providing information and expanding the knowledge of producers and consumers about organic food, etc.

Organic farming has proven its positive effects on the agricultural sector - it directly contributes to preserving the environment and ecosystems, restoring natural resources, developing rural areas. It can stabilize the incomes of Bulgarian farmers through the opportunity to provide healthy food products on new markets. Thus, the competitive advantage of the natural and climatic conditions in our country and the support of the European funds will be reimbursed in economic benefit by the farmers.

\section{ACKNOWLEDGMENTS}

This research was established as a part of Project № M05/4“Production capacity and local consumption of organic products from livestock breeding in Southeast Region" funded by National Scientific research fund and the Ministry of science and education of Republic of Bulgaria.

\section{REFERENCE}

1. Kostadinova, P., Popov, Vl., Basic Principles and Methods of Organic Agriculture, New Knowledge, Year 1, ed. V.UUAR, Plovdiv, Issue 3: p.58, 2012

2. Krusteva, Il., State and Trends for the Development of Bio-Production in Bulgaria for the Period 2006-2012, Reports from the Jubilee Conference "The National Agrarian Sector - an element of the European agricultural regions in the Europe 2020 Strategy" . "Tsenov" Svishtov, p.179, 2014

3. Ministry of Agriculture and Foods Development of Organic Farming in Bulgaria, Report, 2014

4. COUNCIL REGULATION (EC) N: 2092/91 on organic production of agricultural products and indications referring thereto on agricultural products and foodstuffs. Official Journal of the European Communities No L 189 / 1.20. 7. $2007 \mathrm{http} / / /$ europa.eu/scadplus/leg/en/lvb/
5. VIFOAM (International Federation of Organic Agriculture Movements): webpage at: www.ifoam.org.

6. Lampkin, N., Organic Farming, 2002. Old Pond Publishing Ltd. ISBN: 9781903366295; ISBN (Ten digit): 1903366291.

http://www.booksunlimited.ie/Books/Lamp kin-N//Organic-

Farming/9781903366295.htm

7. Balieva, G. N., Huliyan, M., Production and supply of regional food products incentives and challenges for small holdings in Bulgaria. International Journal of Science and Research, Online ISSN 2319-7064, 4 (2): 576-580, February 2015, (Available at: http://www.ijsr.net/archive/v4i2/v4i2_01.ph p\#sthash.ablyMD1V.dpbs)

8. FiBL and IFOAM, The world of organic agriculture, Statistics and emerging trends, 2015 , https://www.fibl.org/fileadmin/documents/s hop/1663-organic-world-2015.pdf

9. Eurostat: Farm Structure Survey data (holdings, age and sex of farm managers, education and vocational training): http://epp.eurostat.ec.europa.eu/portal/page/ portal/statistics / Search_database V / Eurostat: data on the organic sector (area, crop and animal products, operators): http: //epp.eurostat.ec.europa. Eu / portal / page / portal / statistics / search_database

10. Agricultural Report of MAF

11. Agricultural Report of MAF

12.FiBL and IFOAM, The world of organic agriculture, Statistics and emerging trends, 2015 ,

https://www.fibl.org/fileadmin/documents/s hop/1663-organic-world-2015.pdf

13.Regulation № 4 of 24.02.2015 on the implementation of Measure 11 "Organic farming" of the RDP for the period 20142020

14. Mitova, D., Organic production - priority of the Bulgarian agriculture in the new programming period 2014-2020, Economics and Management of Agriculture, issue 3: 4-7, 2014, EIA, Sofia

15.Gonzalvez, V., Schmid, H.W., Organic Action Plans in Europe in 2011. In: Wilier, H. and Kilcher, L. eds., 2011 